\title{
ADR Effects on Domestic Latin American Financial Market
}

\section{Los efectos ADR en los mercados domésticos financieros de Latinoamérica}

\section{Alfredo Mendiola ${ }^{1}$}

\begin{abstract}
The purpose of this paper is to revisit and extend previous research work that examines the ADR-listing effects on the trading process of all the domestically-listed stocks in the main Latin American exchanges. The most important result is consistent with the idea of a greater isolation (from global markets) of the singly-listed stocks in the post-cross-listing period. These results persist over the cross-listing months. As expected, the cross-listed stocks become more integrated in the post-cross listing period.
\end{abstract}

Keywords: International finance, economic integration

\section{Resumen}

El propósito de este artículo es revisar y extender trabajos de investigación en que se examinan los efectos de emitir ADRs en el proceso de negociación de las acciones listadas en los mercados de valores latinoamericanas. El resultado más importante es consistente con la idea de un mayor aislamiento (de mercados financieros internacionales) de las acciones listadas únicamente en el mercado doméstico en el período posterior a la emisión de los ADRs. Estos resultados son persistentes en el tiempo. Como era de esperarse, las acciones sobre las que se han emitido ADRs se encuentran más integradas con mercados financieros internacionales en períodos posteriores a la emisión de este.

Palabras claves: Finanzas internacionales, integración económica

1. Professor Alfredo Mendiola is Ph. D. in Management Finances from Cornell University, USA. He also holds a MBA from the University of Toronto, Canada; a MBA from Esan Business School, Peru. He is a B.of Sc. in Systems Engineer from the Universidad Nacional de Ingeniería del Peru. 
Research has established that cross listing significantly affects the ADR's underlying share ${ }^{1}$ trading process in the domestic exchange. Examples of these effects include higher valuations and improvements in an investor's appreciation of the firm's information (Coffee, 1999; Reese \& Weisbach, 2002; Doidge, Karolyi, \& Stulz, 2003); declines in cost of capital (Errunza \& Miller, 2000; Foerster \& Karolyi, 1993, 1999; Domowitz, Glen, \& Madhavan, 1998); positive abnormal stock returns in the pre-cross-listing period (Foerster \& Karolyi, 1993, 1999; Jayaraman, Shastri, \& Tandon, 1993; Viswanathan, 1996; Miller, 1999; Errunza \& Miller, 2000; Kim \& Singal, 2000); improvement in firm visibility and information environment (Baker, Nofsinger, \& Weaver, 2002; Lang, Lins, \& Miller, 2003; Bailey, Karolyi, \& Salva, 2006); spillover of cross-listing effects to singly-listed stocks (Fernandes, 2003; Melvin \& Valero-Tonone, 2003; Lee, 2003); a migration of trading volume (Smith \& Sofianos, 1997; Pulatkonak \& Sofianos, 1999; Levine \& Schmukler, 2003; Domowitz, Glen, \& Madhavan, 1998). The purpose of this paper is to revisit and extend previous research work that examines the ADR-listing effects on the stock returns of all domestically-listed stocks in Latin American exchanges. Initially, the analysis is done considering the singly- and cross-listed stocks separately; next, all the information of the domestically-listed stocks is pooled to determine possible differences in the trading process across the two groups of securities.

This approach builds on previous research work ${ }^{2}$ and, additionally, takes into consideration three important factors affecting ADR listings. First, including only Latin American stocks ensures that the time zone differences across local and US exchanges are, at most, two hours. ${ }^{3}$ Second, to facilitate the identification of

1 The underlying share refers to the ADR's share traded in the local (non-US) exchange. For example, Teléfonos de México (Telmex) traded in the Mexican stock exchange.

2 For example, you may refer to Foerster and Karolyi, 1999; Miller, 1999; Lee, 2003; Fernandes, 2003; Karolyi, 2004.

3 The rationale behind this argument follows from Pulatkonak and Sofianos (1999). These authors find a strong relation between time zone differences (across domestic and US exchanges) and the strength of volume migration associated spillovers ${ }^{4}$, the examination of ADR-listing effects is done separately on singly- and cross-listed stocks; in a subsequent step, all the information (from the singly- and cross-listed stocks) is pooled to determine whether differences exist across these two groups of securities. Third, Heckman's (1979) procedure is used to control for the differences in the characteristics of the firms with cross- and singly-listed stocks; without this procedure, a non random sample selection occurs given that the behavior of cross- and singly-listed stocks is examined separately.

The main results of this paper are as follows: ADRlisting effects on the domestically-listed stocks are significant and affect singly- and cross-listed stocks in different ways. As expected, ADR-listing results in an increase in the importance of the world exchange index in explaining the behavior of cross-listed shares. However, for the singly-listed shares, ADR-listing induces a significant increase in the importance of the domestic exchange variables to explain the trading behavior of this group of stocks. I interpret this finding as an increase in the isolation (from international markets) of singly-listed shares in the post-cross-listing period.

This paper is organized as follows: The first section includes a summary of the sources and characteristics of the data used for empirical tests. Section two presents a discussion of Heckman's technique and its empirical implementation to determine the Inverse Mills Ratio (probability of cross-listing) for each stock. The behavior of the stock returns is included in the third section.

\section{DATA}

The information collected includes firm and exchange related information from four Latin American countries:

with stock cross-listings. Given the fact that the time zone difference across Latin American and US exchanges is, at the most, two hours, the cross-listing effects across these exchanges would tend to be similar.

4 The direction of these spillover effects are believed to be from the cross-listed to the singly-listed stocks. 
Argentina, Brazil, Chile and Mexico. ${ }^{5}$ The period analyzed extends from January 1, 1992 to December 31, $2002^{6}$. The total number of firm / shares considered in the sample is 926, of which 203 (22\%) have cross-listed securities (See Table 1).

To minimize the possibility of a non-synchronous trading bias, I exclude the securities that trade in less than $30 \%$ of the available trading days. ${ }^{7}$ As Campbell, Lo and MacKinlay (1997) indicate "the non-synchronous trading or non-trading effect arises when time series, usually asset prices, are taken to be recorded at time intervals of one length when in fact they are recorded at time intervals of other, possibly irregular, lengths..." (p. 84). For example, this problem may occur if it is assumed that daily closing prices are recorded at the end of the trading day. As Campbell et al. specifically indicate, this effect may introduce biases in the "moments and co-moments of asset returns such as their means, variances, betas and autocorrelations..." (p. 84). Scholes and Williams (1977) examine this problem and show that for actively traded stocks, any adjustment to control for non-trading effects are generally small and unimportant. Consequently, limiting the sample to include only the most liquid stocks minimizes the possibility of biasing the results due to non-trading effects, improving the quality of the empirical results. ${ }^{8}$

If we exclude the securities traded in less than $30 \%$ of the available trading days, the total number of firmshares drops from 926 to 453 (51\% reduction in the sample size). Furthermore, with this control the number of singly-listed firm-shares included in the sample decreases from 723 to 292 (60\% reduction); for the

5 Information from Colombia, Peru and Venezuela stock exchanges was collected. The small market capitalization and limited liquidity of these markets determined their exclusion from the sample.

6 This sample period is consistent with post-liberalization periods included in Blair (2000) in all four countries.

7 The empirical implementation of the different tests is done considering $40 \%$ and $50 \%$ as benchmark. The final conclusions are not significantly affected.

8 A similar control was implemented by Bailey and Chung (1995). cross-listed firm-shares the sample size decreases from 203 to 161 (21\% reduction). When trading in, more than $40 \%$ and $50 \%$ of the possible days is considered as a benchmark, the total sample size is reduced to 395 and 347 firm-shares, respectively. The proportion of singly- and cross-listed firm-shares excluded from the sample is in line with the previously indicated information (see Table 1).

Daily stock information has been collected from DataStream and includes closing prices, traded volume, and market capitalization. This information was collected in the country's domestic currency and then converted to US Dollars to facilitate cross-sectional analysis ${ }^{9}$. The firm's accounting information, necessary for the implementation of Heckman's procedure, was obtained from the WorldScope database available through DataStream. All information has been collected in home country currency. Exchange related information has also been collected from DataStream and includes the domestic stock exchange index and the MSCI World Stock exchange index. To facilitate the cross-sectional analysis across exchanges, all the information has been converted to US dollars.

\section{HECKMAN'S PROCEDURE TO CONTROL FOR SAMPLE SELECTION BIASES}

The firms that cross list stocks are believed to be the largest and most successful organizations in their home countries. As such, examining the behavior of the singly- and cross-listed stocks separately induces

9

DataStream provides the following definitions for each data item:

- Closing price (CP): "latest price available to us (Datastream) from the appropriate market in primary units of currency."

- Traded volume (Vol): "number of shares traded for a stock on a particular day. The figure is always expressed in thousands."

- Market capitalization (MCap): "Share price multiplied by the number of ordinary shares in issue... displayed in millions of units of local currency." 
a sample selection bias. To control for this possibility, the implement Heckman's procedure has been implemented. ${ }^{10}$

This sample selection problem can be summarized as follows ${ }^{11}$ : Consider a random sample of I observations. For each observation $i$ the following equations can be defined:

$$
\begin{aligned}
& Y_{1 i}=X_{1 i} \beta_{1}+U_{1 i} \\
& Y_{2 i}=X_{2 i} \beta_{2}+U_{2 i}
\end{aligned}
$$

where $X_{j i}$ is a $(1 \mathrm{x} \mathrm{K})$ vector of regressors and $\beta_{j}$ is a $\left(\mathrm{K}_{\mathrm{j}}\right.$ $\mathrm{x} 1$ ) vector of parameters. Suppose that data is available for $Y_{1 i}$ if $Y_{2 i} \geq 0$; if $Y_{2 i}=0$ then there are no observations for $Y_{1 i}$. The general idea is to develop a two-stage estimator to overcome any possible bias related to the non random sample selection due to limitations in the information on $Y_{1 i}$. In this dissertation, $Y_{2 i}=0(1)$ if the stock is singly- (cross-) listed.

Heckman's procedure is implemented as follows:

1. Use the full sample of listed stocks to estimate a probit regression to determine the probability that $Y_{2 i} \geq 0$ (the stock is cross-listed or singlylisted). The independent variables included in this regression represent the general characteristics of all the domestically-listed firms such as market capitalization, leverage ratio, asset turnover and return on equity.

2. Following Heckman's notation, define $\varphi(\cdot)$ as the density function and $\Phi(\cdot)$ as the distribution function of a standard normal variable. Using the coefficients estimated in the probit regression and assuming that $\mathrm{h}\left(U_{1 i}, U_{2 i}\right)$ (error-terms of equations 1 and 2) is bivariate normal, the following parameters (for each of the domesticallylisted stock) can be estimated:

$$
Z i=-\frac{X_{2 i} \beta_{2}}{\sqrt{\sigma_{22}}}
$$

$$
\lambda_{i}=\frac{\varphi\left(Z_{i}\right)}{1-\Phi\left(Z_{i}\right)}
$$

where $\lambda_{i}$ is known as the inverse of Mill's ratio. This ratio is a correction term that is used to control for the bias that arises from the non-random sample selection. As the probability of being in the sample (i.e. cross-listed share) increases, the cumulative density function approaches one and the probability density function approaches zero, so the Inverse Mill's ratio approaches zero.

3. For the estimation of equation 1 coefficients, the Inverse Mill's ratio $\left(\lambda_{i}\right)$ is included as one of the independent variables. Heckman demonstrates that under the previously indicated assumptions the regression estimators (coefficients of $X_{1 i}$ and $\lambda_{1}$ in equation 1) are consistent. Puhani (2000) conducts different Monte Carlo exploratory studies around Heckman's procedure. His results show that, in the absence of collinearity, a "full information maximum likelihood estimator is preferable to the limited-information two-step method of Heckman... If, however, collinearity problems prevail, subsample OLS (or the twopart model) is the most robust amongst the simple-to-calculate estimators" (p. 54).

As previously indicated, Heckman's procedure is a two-stage procedure. In this sub-section, the first step is implemented (i.e. the estimation of the Inverse Mill's ratio for each stock). This ratio is included as one of the independent variables in different regressions to be implemented in later sections of this chapter.

To implement step 1 probit regression, the following independent variables that characterize the domesticallylisted firms $\left(\mathrm{X}_{2 \mathrm{i}}\right.$ in equation 2$)$ are included:

- Market capitalization (MC) to proxy for firm's size. Larger firms are believed to be the most important in their home countries and should tend to be crosslisting targets.
10 Refer to Heckman (1979) and Puhani (2000).
11 This summary is from Heckman. 
- Return on equity (ROE) as a profitability measure of a shareholder's investment ${ }^{12}$. Profitable firms should tend to be cross-listing targets. Another possible argument is that firms with a low ROE cross list to force an improvement in their performance.

- Leverage ratio (LR) to proxy for the firm's financial risk $^{13}$. The rationale is that a higher leverage ratio should lower cross-listing possibilities. Another possible interpretation of this factor is that highly levered firms will cross list to redefine their capital structure.

- Asset turnover (ATu) to measure the firm's operational efficiency ${ }^{14}$. The most efficient firms should tend to be cross-listing targets. Another (opposite) argument is that inefficient firms will cross-list to precipitate changes that will improve asset turnover.

- Dummy for utility firms ( $\left.\mathrm{D}^{\text {utility }}\right)$. A significant proportion of the cross-listed firms correspond to this economic sector (electricity and telecommunication firms).

- Dummy for financial sector (DFinancial). Banks are believed to be important cross-listing targets.

The Pearson Correlation Coefficients across the previously indicated variables are presented in Table 2 . The general picture is consistent with the idea that no strong correlations are observed across these variables.

Table 3 presents the average values of the firm characteristic variables that are included in the determination of probit regression of Heckman's procedure (Step 1). The information is subdivided across singly- and crosslisted stocks. As expected, the firms with cross-listed shares are bigger and more profitable, if measured by the return of equity ratio.

Finally, to implement Step 1 of the Heckman's procedure, the following probit regression equation

\footnotetext{
12 Return on equity $=$ ROE $=$ After tax net income $/$ Shareholder's equity

13 Leverage ratio $=\mathrm{LR}=$ Total liabilities $/$ Total assets

14 Asset turnover $=\mathrm{ATu}=$ Total sales $/$ Total assets.
}

is estimated:

$\mathrm{D}_{i}^{\text {crosslisted }}=\beta_{0}+\beta_{1}$ Mkt_Capitalization ${ }_{i}+\beta_{2} R_{-} O E_{i}+$ $\beta_{3}$ Leverage_Ratio $_{i}+\beta_{4}$ Asset_Turnover $_{i}+$

$\beta_{5} D_{i}^{\text {utility }}+\beta_{6} D_{i}^{\text {financial }}+U_{2 i}$

where $D_{i}^{\text {cross_ }}$ listed $_{\text {is }}$ a dummy variable that takes a value of 1 (0) if firm $i$ stock is cross- (singly-) listed.

Regarding the implementation of the Heckman's procedure two final points must be noted. Firstly, as demonstrated by Heckman, including the Inverse Mills Ratio as an independent variable in subsequent regression estimations should control for any possible differences across singly- and cross-listed stocks that may bias the results. In other words, including this ratio as one of the independent variables will control for the previously indicated differences in size and profitability across singly- and cross-listed stocks. Secondly, in the paper the implementation of Heckman's procedure is neither directed toward examining any differences in the firms with singly- and cross-listed shares nor in the characteristics of the firms that cross-list shares. Instead, this procedure is implemented to estimate a variable (Inverse Mills Ratio) that will be used to control for possible differences across the firms with singly- and cross-listed stocks.

Table 4 - Panel A reports equation (5) estimated coefficients after pooling all the information from the four exchanges included in the sample: Argentina, Brazil, Chile and México. The total number of firm-year information is 3,134, of which 765 correspond to firms with cross-listed shares. The Market Capitalization coefficient is significantly negative. The return on equity (ROE) coefficient is non-significant. The coefficients for the Leverage Ratio and Asset Turnover are significant and evidence that the firm's financial risk and operational efficiency are taken into consideration to the define the possibility of ADR-listing ${ }^{15}$. The utility sector dummy

15 The Pearson correlation coefficient across these two variables is small and significant. 
coefficient ( $\left.\mathrm{D}^{\text {utility }}\right)$ is significant and negative. The coefficient for the financial sector dummy $\left(\mathrm{D}^{\text {Financial }}\right)$ is not significant. These results are included in equations 3 and 4 to determine the Inverse Mills Ratio of each firm.

Similarly, Table 4 - Panel B reports equation (5) estimated coefficients for each of the four countries included in the sample. Even though most of these coefficients have the same sign and significance as the ones presented in Table 4 - Panel A, some differences can be appreciated. For example, for Chile and Brazil, the asset turnover and leverage ratio coefficients respectively are not statistically significant from zero.

Taking into consideration the country differences in the estimation of the probit regression (equation (5)) coefficients, Table 4 - Panel B coefficients will be used to estimate the Inverse Mills Ratio for each firm (Equations (3) and (4)). These ratios will be used in the regression analysis described in latter sections.

\section{STOCK RETURNS}

Research has established that there are significant differences in the pre- and post-cross-listing excess returns of the ADR's underlying shares. Miller (1999) reports significant cross-sectional differences across pre- and post-cross-listing ADR-stock returns; at the same time, he argues that these results are consistent with the idea that ADR-listing limits the negative effects of trading barriers, facilitates risk diversification and, consequently, reduces the investor's required returns. Errunza and Miller (2000) report a significant decline in buy-and-hold ADR-stock returns across the ADR's pre- liberalization period (months -36 to -7 before cross-listing) and the post liberalization period (months +7 to +36 ).

Foester and Karolyi (1999) state that the reduction in the ADR's underlying share returns for the post-crosslisting period are explained by a decrease in the risk perceived by investors, as they have access to better information about the ADR issuer. These arguments are consistent with Merton's (1987) incomplete information asset pricing model, Amihud and Mendelson's (1986) liquidity analysis, and Kladec and McConnell's (1994) examination of the reactions in the stock trading process to changes of trading venue.

Fernandes (2003) uses a sample of individual firms from 27 emerging markets to examine the spillover effects of the first ADR-listing. He finds a spillover effect (as predicted by Alexander et al. (1985) asset pricing model) that results in a decrease in the expected returns across all domestically-listed stocks. Melvin and Valero-Tonone (2003) report that rivals of an ADRissuing firm that list in the local market are negatively affected by cross-listing: there is a reduction in the rival firm's excess return around the announcement and listing day ${ }^{16}$.

To implement the empirical tests, when necessary, the daily stock information is summarized into weekly periods ${ }^{17}$. For each week, the last available daily price is considered to be the end-of-the-week closing price $(\mathrm{CP})$. The weekly stock return $\left(\mathrm{R}_{\mathrm{i}, \mathrm{t}}\right)$ for stock $\mathrm{i}$ in week $\mathrm{t}$ is defined as:

$$
R_{i t}=\frac{C P_{i, t}-C P_{i, t-1}}{C P_{i, t-1}}
$$

To estimate weekly stock excess returns $\left(\mathrm{r}_{\mathrm{i}, \mathrm{t}}\right)$, the US T-Bill (30 day maturity) return $\left(\mathrm{Rf}_{\mathrm{t}}\right)$ is considered to be risk-free, such that:

$$
r_{i, t}=R_{i, t}+R f_{t}
$$

The procedure used to calculate the end-of-the-week index returns is similar to that used for stock returns.

16 Melvin and Valero-Tonone argue that this situation may "evidence that investors see rivals as less transparent, less informative and with poorer growth prospects relative to the listing firm." (Working Paper, Tempe, Arizona State University).

17 The IAPM coefficients were also estimated using monthly information. The statistical significance of the results was low. A possible explanation for this situation refers to the high price variability that is observed in these exchanges. Apparently, Foerster and Karolyi (1999) had a similar problem, as they used weekly information to estimate a similar IAPM. 
The international asset pricing model (IAPM) implemented by Foerster and Karolyi (1999) is used to determine whether there are cross-sectional differences across the pre- and post-cross-listing weekly excess returns of the singly- and cross-listed stocks. ${ }^{18}$ This model relates the excess returns on the stocks, domestic market exchange index, and world exchange index for the pre-, during and post-cross-listing weeks, such that:

$$
\begin{aligned}
& r_{i t=} \alpha_{k}^{p r e}+\beta_{k d}^{p r e} r_{k t}^{\text {local }}+\beta_{k w}^{\text {pre }} r_{t}^{\text {world }}+\alpha_{k}^{\text {list }} D_{i t}^{\text {list }}+ \\
& \alpha_{k}^{\text {post }} D_{i t}^{\text {post }}+\beta_{k d}^{\text {post }} r_{k t}^{\text {local }} D_{i t}^{\text {post }}+\beta_{k w}^{\text {post }} r_{t}^{\text {world }} D_{i t}^{\text {post }}+ \\
& \beta_{i} \lambda_{i}+\text { Year_Controls }+ \text { Country_Controls }+ \\
& \text { Post 1997_Control }+\varepsilon_{i t}
\end{aligned}
$$

where $r_{i t}$ refers to the weekly excess returns of stock $i$ in period $t$. The variables $\mathrm{r}_{k t}^{\text {local }}$ and $r_{t}^{\text {world }}$ correspond to the weekly excess return of the $k^{\text {th }}$ domestic stock exchange index (where stock $i$ is listed) in period $t$ and the world stock exchange index, respectively. $D_{i t}^{\text {list }}$ and $D_{i t}^{\text {post }}$ are dummy variables to control for the listing and post-cross-listing periods, respectively. $\lambda_{i}$ is stock $i$ average Inverse Mills ratio, and it is included to control for any possible problem related to non-random sample selection. To control for potential country-differences and time trends, the corresponding dummy variables are included. Additionally, a post-1997 dummy variable is included to control for possible differences across the pre- and post-Asian crisis. ${ }^{19}$

As previously indicated, the examination of ADRlisting effects on singly- and cross-listed stocks is done separately for each. For the cross-listed stocks, equation (8) estimates coefficients using 24 months of stock and exchange information around the ADR's cross-listing

18 Fernandes (2003) uses monthly information to implement a similar IAPM. Foerster and Karolyi (1999) use weekly returns.

19 Levine and Schumukler (2003) find evidence that the intensity of information flows across Asian and US exchanges increased after the 1997 Asian crisis. O'Hara (2001) considers that there are significant changes in the performance of Latin American exchanges after 1994. date. ${ }^{20}$ To examine the cross-listing spillover effects on singly-listed stocks, equation (8) estimates coefficients considering 24 months of information around the first three ADR-listing days. ${ }^{21}$ The statistical significance of $\alpha_{k}^{\text {post }}, \alpha_{k}^{\text {post }}, \beta_{k d}^{\text {post }}$ and $\beta_{k w}^{\text {post }}$ coefficients is used to examine the ADR-listing effects.

To examine whether the cross-listing effects spread uniformly to the singly- and cross-listed stocks, all the information (of singly- and cross-listed stocks) is pooled to estimate the IAPM coefficients (Equation (8)). In this case, the dummy variables $D_{i t}^{l i s t}$ and $D_{i t}^{\text {post }}$ are equal to 1 for the ADR-stocks in the cross-listing and post-crosslisting periods, respectively. Similarly, the statistical significance of $\alpha_{k}^{\text {list }} \alpha_{\mathrm{k}}{ }^{\text {post }}, \alpha_{k}^{\text {post }} \alpha_{\mathrm{k}}{ }^{\text {post }}, \beta_{k d}^{\text {post }}$ and $\beta_{k w}^{\text {post }}$ will provide evidence of the existence of the previously indicated differences.

Table 5 reports the equation (8) estimated coefficients for the cross-listed stocks traded in more that $30 \%$ of the available trading days. The reported regression coefficients correspond to five different combinations of the year, country and post-1997 control variables. In all five regressions, the coefficients of the interactive terms $\mathrm{s}^{22}$ are significant, have the expected sign, and are consistent with the idea that cross-listing determines an increase (decrease) in the importance of the world (domestic) stock exchange index to explain the ADR's underlying stock returns in the post-cross-listing period ${ }^{23}$.

Table 6 reports the equation (8) estimated coefficients for the singly-listed stocks traded in more that $30 \%$ of the available trading days. Dummy variables are included to control for possible country differences. In addition, dummy variables are included to control for

2012 months before and after the cross-listing week.

21 For the singly-listed stocks, additional dummy variables are included to control for the $2^{\text {nd }}$ and $3^{\text {rd }}$ ADR listing.

22 Return Domestic Exchange Index * Dummy for the postcross-listing period, and Return World Exchange Index * Dummy for the post-cross-listing period.

23 Similar regressions considering the cross-listed stocks traded in more than $40 \%$ and $50 \%$ of the available trading days were estimated. The previously indicated conclusions are not affected by this sample change. 
possible differences across the first, second and third ADR listing effects. As all the first three ADR-listings occurred before 1997, the inclusion of this control variable is not relevant. Similarly, year dummies are not included as they are strongly correlated with the first, second and third ADR-listing dummy. The results highlight significant positive abnormal returns for the post-cross listing period. In addition, the coefficients of the interactive terms emphasize that the singly-listed stocks become more isolated from world markets for the post-cross-listing period (i.e. the importance of the world index returns to explain the stock returns decreases for the post-cross-listing period) ${ }^{24}$.

Given the nature of the results (i.e. isolation of singlylisted stocks) it is important to examine the long-run persistence of these effects. To examine this possibility the following regression is estimated:

$$
\begin{aligned}
& r_{i t}=\alpha_{k}+\beta_{k d} r_{k t}^{\text {local }}+\beta_{k w} r_{t}^{\text {world }}+\beta_{k} \lambda_{k}+ \\
& \sum_{y=1993}^{2002} \beta_{k d}^{y} r_{k t}^{\text {local }} D^{y}+\sum_{y=1993}^{2002} \beta_{k w}^{y} r_{t}^{\text {world }} D^{y}+\varepsilon_{i t}
\end{aligned}
$$

where $r_{i t}$ refers to the weekly excess returns for singly-listed stock $i$ in period $t$. The variables $r_{i t}^{\text {local }}$ and $r_{t}^{\text {world }}$ refer to the excess return in week $\mathrm{t}$ on the $\mathrm{k}$-th domestic stock exchange (were stock $\mathrm{i}$ is listed) and the world market portfolio, respectively. $D^{y}$ is a dummy variable that takes a value of 1 for year $y$. $\lambda_{k}$ is the average Inverse Mills ratio for each stock, and is included to control sample selection bias. The information corresponds to the stock and exchange information after the fourth, fifth and sixth ADR listing.

Table 7 reports equation (9) estimated coefficients considering the singly-listed stocks traded on more than $30 \%$ of the available trading days. The results indicate that the return on the local index, if compared with the

24 Similar regressions considering the singly-listed stocks traded on more than $40 \%$ and $50 \%$ of the available trading days were estimated. The conclusions previously indicated are not affected by this sample change. return on the world index, explains a larger portion of the singly-listed stock return. From 1995 to 2001, all the local index return coefficients are significant; for the same period only two world index return coefficients are significant. An F-Test is implemented to determine if the local index and world index return coefficients were significantly different from zero. Although the results indicate that both sets of coefficients ${ }^{25}$ are significantly different from zero, the results for the local index return coefficients are much stronger. All of this evidence is consistent with the idea that in the long-run, a significant portion of the singly-listed returns can be explained by changes in the local index returns that provides evidence for a continuous isolation of this type of stock from global markets ${ }^{26}$.

Table 8 reports equation (8) estimated coefficients that correspond to the long-run differences in the returns of the singly- and cross-listed stocks traded in more than $30 \%$ of the available trading days. The coefficients for five different regressions are reported and correspond to different combinations of the year, country and post-1997 control variables. These results provide evidence of significant differences in the excess returns behavior of these two groups of securities. As expected, cross-listed stocks returns are larger (smaller) for the cross-listing (post-cross-listing) week if compared with singly-listed stock returns. The coefficient for the cross-listing (post-cross-listing) week dummy variable is significant and positive (negative); this is evidence that the cross-listed stock returns increase (decrease) during (after) this period. The interactive term Return on World Index * Post-Cross-listing week dummy (significant and positive) provides evidence of a greater integration of cross-listed stocks with world financial markets as compared to singly-listed stocks. In a somewhat unexpected result, in all five regressions, the interactive term Return on Local Index *

25 Local index return coefficients and world index return coefficients.

26 Similar regressions considering the singly-listed stocks traded on more than $40 \%$ and $50 \%$ of the available trading days were estimated. The previously indicated conclusions are not significantly affected by this sample change. 
Post-cross-listing dummy is significant and positive. This result could be related to a greater integration of the exchange with world markets. This possibility will be addressed in future research work ${ }^{27}$.

\section{CONCLUSIONS}

Overall, these results are consistent with the idea that ADR-listing significantly affects the returns of the domestically-listed stocks. The evidence supports the assertion that cross- listed stocks become more integrated with world markets. However, in contrast, there is a significant decrease in the importance of world market returns to explain the behavior of singly-listed stock returns. Consequently, as singly listed stocks become more isolated from world market, investors will demand a return-premium to compensate for additional risk $^{28}$. These results contradict those of Alexander et al. (1987), as they reveal that cross listing effects do not evenly spread to all domestically-listed stocks ${ }^{29}$.

\section{References}

Alexander, G., Eun, C., \& Janakiramanan, S. (1987). Asset Pricing and Dual Listing on Foreign Capital Markets: A Note. Journal of Finance, 42(Mar), 151158.

Amihud, Y. (2000). Illiquidity and stock returns: cross section and time series effects. New York University Stern School of Business. Working Paper N FIN00-041.

Amihud, Y., \& Mendelson, H. (1986). Asset Pricing and the Bid-Ask Spread. Journal of Financial Economics. 17(2), pages 223-249.

Bae, K., Bailey, W., \& Mao, C. (2006). Stock Market Liberalization and the Information Environment. Journal of International Money and Finance, vol.25, issue 3, pages 404-428.

Bailey, W., \& Chung, P. (1995). Exchange Rate Fluctuations, Political Risk and Stock Returns: Some Evidence from an Emerging Market. Journal of Financial Quantitative Analysis, vol. 30(4), 541-561.

Bailey, W., Karolyi, A., \& Salva, C. (2006). The Economic Consequences of Increased Disclosure: Evidence from International Cross-listings. Journal of Financial Economics, 81, 175-213.

27 Similar regressions considering all the domestically-listed stocks traded on more than $40 \%$ and $50 \%$ of the available trading days were estimated. The conclusions previously indicated are not affected.
Baker, K., Nofsinger, J., \& Weaver, D. (2002). International Cross-listing and Visibility. Journal of Financial and Quantitative Analysis, 37(3), 495-521.

Campbell, J., Lo, A., \& Mackinlay, A. C. (1997). The Econometrics of Financial Markets. Princeton, $N J$ : Princeton University Press.

Coffee, J. (1999). The Future as History: The Prospects for Global Convergence in Corporate Governance and its implications. Northwestern University Law Review, 93, 641-708.

Doidge, C., Karolyi, A., \& Stulz, R. (2004). Why are Foreign Firms Listed in the US Worth More? Journal of Financial Economics, 71, 205-238.

Domowitz, I., Glen, J., \& Madhavan, A. (1997). Market Segmentation and Stock Prices: Evidence from an Emerging Market. The Journal of Finance, vol.52, issue 3, pages 1059-1085.

Domowitz, I., Glen, J., \& Madhavan, A. (1998). International Cross Listing and Order Flow Migration: Evidence from an Emerging Market. The Journal of Finance, LIII(6), 2001-2027.

28 See Stulz (1981), Errunza and Losq (1985).

29 A possible explanation for these differences is that the assumptions behind Alexander et al. model are not satisfied in Latin American exchange markets. In particular, short sales and fixed exchange rates are not available in Latin American markets. 
Errunza, V., \& Losq, E. (1985). International Asset Pricing under Mild Segmentation: Theory and Test. Journal of Finance, 40(March), 105 - 124.

Errunza, V., \& Miller, D. (2000). Market Segmentation and the Cost of Capital in International Equity Markets. Journal of Finance and Quantitative Analysis, 35(4), 577-600.

Fernandes, N. (2003). Market Liberalization: Spillovers from ADRs and implications for local markets. Barcelona: IESE Business School.

Foerster, S., \& Karolyi, A. (1993). International Listings of Stocks: The Case of Canada and the US. Journal of International Business Studies, 24, 763 - 784.

Foerster, S. \& Karolyi, A. (1998). Multimarket Trading and Liquidity: A Transaction data analysis of CanadaUS interlistings. Journal of International Financial Markets, 8

Foerster, S., \& Karolyi, A. (1999). The Effects of Market Segmentation and Investor Recognition on Asset Prices: Evidence from Foreign Stocks Listing in the United States. Center for Research Financial Economics, working paper $N^{\circ}$ 98-11.

Heckman, J. (1979). Sample Selection Bias as a Specification Error. Econométrica, 47(1), 153-161.

Henry, P. B. (2000). Do Stock Market Liberalization Cause Investment Booms? Journal of Financial Economics, 58, 301-334.

Jayaraman, N., Shastri, K., \& Tandon, K. (1993). The impact of International cross listings on risk and return: Evidence from American Depositary Receipts. Journal of Banking and Finance, 17, 91-103.

Karolyi, A. (2006). The World of Cross Listing and Cross Listings of the World: Challenging Conventional Wisdom. Oxford Journals: Review of Finance, 10, 99-152.

Kim, E., \& Singal, V. (2000). Stock market openings: experience of emerging economies. Journal of Business, 73(1), 25-66.

Kladec, G., \& McConnell, J. (1994). The Effect of Market Segmentation and Illiquidity on Asset Prices: Evidence from Exchange Listings. The Journal of Finance, XLIX(2 June), 611-636.
Lang, M., Lins, K., \& Miller, D. (2003). ADRs, Analysts and Accuracy: Does Cross Listing in the US Improve a firm's information environment and Increase Market Value?. Journal of Accounting Research, 41(2), 317-345.

Lee, D. (2003). Why does shareholder wealth increase when NON-US firms announce their listing in the U.S.?. Korea University Business School. Available at SSRN: $<$ hhtp://ssrn.com/abstract=422960>.

Levine, R., \& Schmukler, S. (2003). Migration, Spillovers and Trade Diversion: The Impact of Internalization on Stock Market Liquidity (Working Paper 9614). Cambridge, MA: NBER.

Melvin, M., \& Valero-Tonone, M. (2003). The Effects of International Cross-Listing on Rival Firms. Tempe: Carey School of Business, Arizona State University.

Merton, Robert C. (1987). A Simple Model of Capital Market Equilibrium with Incomplete Information. Journal of Finance, 42, 483-510.

Miller, D. (1999). The market reaction to international cross-listings: evidence from Depositary Receipts. Journal of Financial Economics, 51, 103-123.

O'Hara, M. (2001). Designing Markets for Developing Countries. International Review of Finance, vol. 2, issue 4, pages 205-215.

Parkinson, M. (1980). The Extreme Value Method for Estimating the Variance of the Rate of Return. Journal of Business, 53(1), 61-65.

Puhani, P. (2000). The Heckman Correction for Sample Selection and its Critique. Journal of Economic Surveys, 14(1), 53-68.

Pulatkonak, M., \& Sofianos, G. (1999). The Distribution of Global Trading in NYSE-listed Non-US stocks (Working Paper w99-03). New York: NYSE.

Reese, W. A., \& Weisbach, M. (2002). Protection of Minority Shareholder Interest, Cross-listing in the United States and Subsequent Equity Offerings. Journal of Financial Economics, 66, 65-104.

Scholes, M., \& Williams, J. (1997). Estimating Betas from Nonsynchronous Data. Journal of Financial Economics, 5, 309-327. 
Smith, K., \& Sofranos G. (1997). The Impact of an NYSE Listing on the Global Trading of Non-US Stocks. (Working Paper w97-02). New York: NYSE.

Stultz, R. (1981). On the Effects of Barriers to International Investment. Journal of Finance, 36(4), 923-934.
Viswanathan, K. G. (1996). Listing in the U.S. Markets by Foreign Firms: Evidence on Return and Risk. Advances in International Banking and Finance, 2, 99-113. 
Table 1.

Number of Firm-Shares

\begin{tabular}{|c|c|c|c|c|c|c|c|}
\hline \multirow{2}{*}{$\begin{array}{l}\text { Proportion of } \\
\text { trading days }\end{array}$} & \multirow[b]{2}{*}{ Country } & \multirow{2}{*}{$\begin{array}{l}\text { Total } \\
\text { listed } \\
\text { shares }\end{array}$} & \multirow{2}{*}{$\begin{array}{l}\text { Cross-listed } \\
\text { firm shares }\end{array}$} & \multirow{2}{*}{$\begin{array}{l}\text { Singly-listed } \\
\text { firm shares }\end{array}$} & \multicolumn{3}{|c|}{ Proportion of } \\
\hline & & & & & $\begin{array}{l}\text { Total number of } \\
\text { listed shares }\end{array}$ & $\begin{array}{l}\text { Cross-listed } \\
\text { firm shares }\end{array}$ & $\begin{array}{c}\text { Singly-listed firm } \\
\text { shares }\end{array}$ \\
\hline \multirow{5}{*}{$\begin{array}{l}\text { All the } \\
\text { sample }\end{array}$} & Argentina & 81 & 19 & 62 & $9 \%$ & $9 \%$ & $9 \%$ \\
\hline & Brazil & 547 & 119 & 428 & $59 \%$ & $59 \%$ & $59 \%$ \\
\hline & Chile & 217 & 26 & 191 & $23 \%$ & $13 \%$ & $26 \%$ \\
\hline & México & 81 & 39 & 42 & $9 \%$ & $19 \%$ & $6 \%$ \\
\hline & Total & 926 & 203 & 723 & $100 \%$ & $100 \%$ & $100 \%$ \\
\hline \multirow{5}{*}{$\begin{array}{l}30 \% \text { of } \\
\text { available } \\
\text { trading days }\end{array}$} & Argentina & 60 & 18 & 42 & $13 \%$ & $11 \%$ & $14 \%$ \\
\hline & Brazil & 227 & 89 & 138 & $50 \%$ & $55 \%$ & $47 \%$ \\
\hline & Chile & 120 & 25 & 95 & $26 \%$ & $16 \%$ & $33 \%$ \\
\hline & México & 46 & 29 & 17 & $10 \%$ & $18 \%$ & $6 \%$ \\
\hline & Total & 453 & 161 & 292 & $100 \%$ & $100 \%$ & $100 \%$ \\
\hline \multirow{5}{*}{$\begin{array}{l}40 \% \text { of } \\
\text { available } \\
\text { trading days }\end{array}$} & Argentina & 51 & 17 & 34 & $13 \%$ & $11 \%$ & $14 \%$ \\
\hline & Brazil & 204 & 86 & 118 & $52 \%$ & $57 \%$ & $48 \%$ \\
\hline & Chile & 102 & 24 & 78 & $26 \%$ & $16 \%$ & $32 \%$ \\
\hline & México & 38 & 24 & 14 & $10 \%$ & $16 \%$ & $6 \%$ \\
\hline & Total & 395 & 151 & 244 & $100 \%$ & $100 \%$ & $100 \%$ \\
\hline \multirow{5}{*}{$\begin{array}{l}50 \% \text { of } \\
\text { available } \\
\text { trading days }\end{array}$} & Argentina & 44 & 17 & 27 & $13 \%$ & $12 \%$ & $13 \%$ \\
\hline & Brazil & 182 & 83 & 99 & $52 \%$ & $57 \%$ & $49 \%$ \\
\hline & Chile & 87 & 24 & 63 & $25 \%$ & $16 \%$ & $31 \%$ \\
\hline & México & 34 & 22 & 12 & $10 \%$ & $15 \%$ & $6 \%$ \\
\hline & Total & 347 & 146 & 201 & $100 \%$ & $100 \%$ & $100 \%$ \\
\hline
\end{tabular}

Note. Number of listed firms in each of the seven Latin American exchanges included in the sample: Argentina, Brazil, Chile, Colombia, México, Peru and Venezuela. The proportion of trading days defines a benchmark to include firm shares in the sample. For example, a proportion equal to $30 \%$ means that the firm shares included in the sample were traded in $30 \%$ o more of the total available trading days. The proportion of listed stocks is equal to proportion (for each country) of the listed shares. 
Table 2.

Pearson Correlation Coefficients of the Firm-Characteristic Variables Included in Probit Regression of Heckman Procedure - Step 1

\begin{tabular}{|c|c|c|c|c|c|}
\hline & $\begin{array}{c}\text { Market } \\
\text { Capitalization }\end{array}$ & $\begin{array}{c}\text { Return on } \\
\text { Equity }\end{array}$ & $\begin{array}{c}\text { Leverage } \\
\text { Ratio }\end{array}$ & Asset Turnover & $\begin{array}{c}\text { Utility Sector } \\
\text { Dummy }\end{array}$ \\
\hline \multirow[t]{2}{*}{ Return on Equity } & 0.01613 & & & & \\
\hline & $(0.3299)$ & & & & \\
\hline \multirow[t]{2}{*}{ Leverage Ratio } & -0.0116 & -0.01472 & & & \\
\hline & $(0.4838)$ & $(0.3741)$ & & & \\
\hline \multirow[t]{2}{*}{ Asset Turnover } & -0.09407 & 0.03887 & -0.05046 & & \\
\hline & $(<0.0001)$ & $(0.0189)$ & $(0.0023)$ & & \\
\hline \multirow[t]{2}{*}{ Utility Sector Dummy } & 0.05204 & 0.00759 & 0.01691 & 0.18049 & \\
\hline & $(0.0017)$ & $(0.6469)$ & $(0.3071)$ & $(<0.0001)$ & \\
\hline \multirow[t]{2}{*}{ Financial Sector Dummy } & 0.0622 & 0.02413 & -0.05399 & -0.22507 & -0.16524 \\
\hline & $(0.0002)$ & $(0.1450)$ & $(0.0011)$ & $(<0.0001)$ & $(<0.0001)$ \\
\hline
\end{tabular}

Note. Market capitalization correspond to end-of-year stock price times the outstanding shares. Leverage ratio is equal to Total Liabilities divided by Total Assets. Return on Equity is equal to Net Income divided by Common Stock. Asset Turnover is equal to Total Sales divided by Total Assets. Utility Sector and Financial Sector dummies are included. All the information has been collected from DataStream

Table 3.

Average Values of the Firm Characteristic Variables

\begin{tabular}{|c|c|c|c|c|c|}
\hline & & & $\begin{array}{c}\text { Singly-listed } \\
\text { stocks } \\
\end{array}$ & $\begin{array}{c}\text { Cross-listed } \\
\text { stocks }\end{array}$ & Difference \\
\hline Number of observations & & & 2,773 & 876 & \\
\hline Market Capitalization & $\begin{array}{l}\text { Stock Price } * \\
\text { Outstanding shares }\end{array}$ & Million dollars & 41.43 & 83.86 & Yes \\
\hline & & & $(204.03)$ & $(224.33)$ & \\
\hline Return on Equity & $\begin{array}{l}\text { Net Income / } \\
\text { Common Stock }\end{array}$ & $\%$ & -7.81 & 1.09 & Yes \\
\hline & & & $(2.24)$ & $(63.29)$ & \\
\hline Leverage Ratio & $\begin{array}{l}\text { Total Liabilities / } \\
\text { Total Assets }\end{array}$ & & 0.27 & 0.31 & No \\
\hline \multirow{3}{*}{ Asset Turnover } & & & $(0.55)$ & $(0.18)$ & \multirow{3}{*}{ No } \\
\hline & $\begin{array}{l}\text { Total Sales / Total } \\
\text { Assets }\end{array}$ & & 0.66 & 0.55 & \\
\hline & & & $(0.59)$ & $(0.37)$ & \\
\hline
\end{tabular}

Note. This table presents the average values of the market and accounting information included in the determination of the Inverse Mills Ratio (Heckman procedure - Step 1). The information is presented for the cross- and singly-listed stocks. Standard deviations are shown in parenthesis. The column labeled difference indicates the results of a t-test of the mean difference. The differences across the dummy variables are not included. 
Table 4.

Heckman's Procedure: Probit Estimates (1st step)

Panel (A): Probit Regression Results - All Information

Variable

Number of observations

Singly listed stocks

Cross listed stocks

Market capitalization

Return on equity

Leverage ratio

Asset turnover

Dummy: Utility sector firm

Dummy: Financial sector firm

\begin{tabular}{r}
\hline Coefficien \\
3,134 \\
2,369 \\
765
\end{tabular}

$\mathrm{MC}$

$-0.0005$

$<0.0001$

ROE

$-0.0005$

0.1424

LR

$-0.0883$

0.0392

$\mathrm{ATu}$

0.1230

0.0204

DuUtil

$-0.6190$

$<0.0001$

DuFin

Note.

The probit regression equation used is:

$\mathrm{D}_{\mathrm{i}}^{\text {cross } \_ \text {listed }}=\beta_{0}+\beta_{1}$ Mkt_Capitalization ${ }_{\mathrm{i}}+\beta_{2} \mathrm{ROE}_{\mathrm{i}}+\beta_{3}$ Leverage_Ratio $_{\mathrm{i}}+$ $\beta_{4}$ Asset_Turnover ${ }_{\mathrm{i}}+\beta_{5}$ D $^{\text {utility }}+\beta_{6}$ D $_{\mathrm{i}}^{\text {financial }}+\mathrm{U}_{2 \mathrm{i}}$

$\mathrm{D}^{\text {cross_listed }}{ }_{\mathrm{i}}$ takes a value of 1 is firm i stock is cross-listed. ROE is firm i return on equity and is equal to Net Income (After Taxes) / Shareholders Equity. Leverage Ratio is equal to Total Liabilities / Total Assets. Asset Turnover is calculated as Total Sales / Total Assets. $\mathrm{D}^{\text {Utility }}$ takes a value of 1 if firm i belongs to a utility sector. $\mathrm{D}^{\text {Financial }}$ takes a value of 1 if the firm i belongs to the financial sector. The total number of firm-observations included is 3134 , of which 2369 correspond to singly-listed firms and 765 to cross-listed firms. The estimated coefficients for the probit regression are as explained in the above table. 
Table 4 (continued).

Panel (B): Probit regression Results by Country

$\frac{\text { Argentina }}{\text { Coefficient } \quad \operatorname{Pr}>\text { ChiSq }}$

\begin{tabular}{cc}
\multicolumn{2}{c}{ Brazil } \\
\hline Coefficient & $\operatorname{Pr}>$ ChiSq \\
\hline
\end{tabular}

Number of observations

Singly listed stocks

194

70

Cross listed stocks

Market capitalization

Return on equity

Leverage ratio

Asset turnover

Dummy: Utility sector firm

Dummy: Financial sector firm

$\begin{array}{lcc}\text { MC } & -0.2106 & 0.0011 \\ \text { ROE } & -0.0009 & 0.5207 \\ \text { LR } & -0.8276 & 0.0859 \\ \text { ATu } & 0.7281 & 0.0393 \\ \text { DuUtil } & -1.2206 & <0.0001 \\ \text { DuFin } & -0.5894 & 0.0518\end{array}$

1,431

459

$\begin{array}{cc}-0.1040 & <0.0001 \\ -0.0004 & 0.3338 \\ -0.0376 & 0.4388 \\ 0.2211 & 0.0030 \\ 0.6435 & <0.0001 \\ 0.5971 & <0.0001\end{array}$

\begin{tabular}{|c|c|c|c|}
\hline \multicolumn{2}{|c|}{ Chile } & \multicolumn{2}{|c|}{ Mexico } \\
\hline Coefficient & $\mathrm{Pr}>\mathrm{ChiSq}$ & Coefficient & $\mathrm{Pr}>\mathrm{ChiSq}$ \\
\hline
\end{tabular}

Number of observations

Singly listed stocks

616

100

$\begin{array}{lcc}\text { MC } & -0.0010 & <0.0001 \\ \text { ROE } & -0.0055 & 0.1059 \\ \text { LR } & -2.2747 & <0.0001 \\ \text { ATu } & 0.2460 & 0.1644 \\ \text { DuUtil } & -0.0359 & 0.8442 \\ \text { DuFin } & -0.7902 & 0.0003\end{array}$

DuFin
128

136

$\begin{array}{cc}-0.0260 & 0.0095 \\ -0.0245 & <0.0001 \\ -1.4329 & 0.0104 \\ 0.2222 & 0.1542 \\ -0.7134 & 0.0690 \\ 0.3199 & 0.2587\end{array}$

Market capitalization

Return on equity

Leverage ratio

Asset turnover

Dummy: Utility sector firm

Dummy: Financial sector firm 
Table 5.

Cross-Listed Stock Returns: Pre- and Post-Cross Listing Differences

\begin{tabular}{|c|c|c|c|c|c|}
\hline & (I) & (II) & (III) & (IV) & $(\mathrm{V})$ \\
\hline \multirow[t]{2}{*}{ Intercept } & -0.0008 & -0.0032 & 0.0006 & -0.0036 & -0.0028 \\
\hline & $(0.18)$ & $(1.08)$ & $(0.30)$ & $(0.79)$ & $(0.93)$ \\
\hline \multirow[t]{2}{*}{ Return - Local Index } & 0.8607 & 0.8636 & 0.8636 & 0.8598 & 0.8632 \\
\hline & $(47.50)$ & $(47.70)$ & $(47.69)$ & $(47.44)$ & $(47.65)$ \\
\hline \multirow[t]{2}{*}{ Return - World Index } & -0.1676 & -0.1573 & -0.1571 & -0.1667 & -0.1576 \\
\hline & $(3.34)$ & $(3.15)$ & $(3.14)$ & $(3.32)$ & $(3.15)$ \\
\hline \multirow[t]{2}{*}{ Cross listing week - Dummy variable } & -0.0032 & -0.0032 & -0.0031 & -0.0032 & -0.0031 \\
\hline & $(0.49)$ & $(0.48)$ & $(0.47)$ & $(0.48)$ & $(0.47)$ \\
\hline \multirow[t]{2}{*}{ Post Cross listing week - Dummy variable } & -0.00002 & -0.0009 & -0.0009 & 0.0003 & -0.0008 \\
\hline & $(0.01)$ & $(0.66)$ & $(0.63)$ & $(0.20)$ & $(0.59)$ \\
\hline \multirow[t]{2}{*}{$\begin{array}{l}\text { Return Local Index * Post cross listing week } \\
\text { dummy }\end{array}$} & -0.0866 & -0.0873 & -0.0871 & -0.0860 & -0.0869 \\
\hline & $(3.64)$ & $(3.67)$ & $(3.66)$ & $(3.62)$ & $(3.65)$ \\
\hline \multirow[t]{2}{*}{$\begin{array}{l}\text { Return World Index * Post cross listing week } \\
\text { dummy }\end{array}$} & 0.1518 & 0.1496 & 0.1494 & 0.1508 & 0.1487 \\
\hline & $(2.37)$ & $(2.34)$ & $(2.33)$ & $(2.36)$ & $(2.32)$ \\
\hline Inverse Mills Ratio & Yes & Yes & Yes & Yes & Yes \\
\hline Year dummies & Yes & & & Yes & \\
\hline Country dummies & & Yes & & Yes & Yes \\
\hline Pre 1997 dummy & & & Yes & & Yes \\
\hline R-Square & 0.30 & 0.30 & 0.29 & 0.30 & 0.29 \\
\hline
\end{tabular}

Note. The sample includes information from Argentina, Brazil, Chile and Mexico for the period January 01, 1992 to December 31, 2002. The stocks traded in less than $30 \%$ of the available trading days are not included in the sample. The reported coefficients correspond to the following International Asset Pricing Model (IAPM):

$$
\begin{aligned}
\mathrm{r}_{\mathrm{it}}= & \alpha_{\mathrm{k}}^{\text {pre }}+\beta_{\mathrm{kd}}{ }^{\text {pre }} \mathrm{r}_{\mathrm{kt}}^{\text {local }}+\beta_{\mathrm{kw}}{ }^{\text {pre }} \mathrm{r}_{\mathrm{t}}^{\text {world }}+\alpha_{\mathrm{k}}^{\text {list }} \mathrm{D}_{\mathrm{it}}^{\text {list }}+ \\
& \alpha_{\mathrm{k}}^{\text {post }} \mathrm{D}_{\mathrm{it}}^{\text {post }}+\beta_{\mathrm{kd}}{ }^{\text {post }} \mathrm{r}_{\mathrm{kt}}{ }^{\text {local }} \mathrm{D}_{\mathrm{it}}{ }^{\text {post }}+\beta_{\mathrm{kw}}{ }^{\text {post }} \mathrm{r}_{\mathrm{t}}^{\text {world }} \mathrm{D}_{\mathrm{it}}^{\text {post }}+\beta_{\mathrm{k}} \lambda_{\mathrm{k}}+\varepsilon_{\mathrm{it}}
\end{aligned}
$$

where $r_{i t}$ refers to the weekly excess returns for stock $i$ in period t. The variables $r_{k t}^{\text {local }}$ and $r_{t}$ world refer to the excess return in week $t$ on the k-th domestic stock exchange (were stock $i$ is listed) and the world market portfolio, respectively. $\mathrm{D}_{\mathrm{it}}{ }^{\text {list }}$ and $\mathrm{D}_{\mathrm{it}}{ }^{\text {post }}$ are dummy variables to control for the cross-listing and post-cross-listing weeks. $\lambda_{\mathrm{k}}$ is the average Inverse Mills ratio for each stock, and is included to control sample selection bias. Following Foerster and Karolyi (1999), 24 months of information around the cross-listing event (12 months before and after the cross listing week) is used to estimate the IAPM coefficients. Dummy variables are included to control for possible country differences and time trends. Robust t-statistics are included in parenthesis. 
Table 6.

Singly-Listed Stock Returns: Pre- and Post-Cross Listing Differences

\begin{tabular}{lcc}
\hline & $(\mathrm{I})$ & $(\mathrm{II})$ \\
\cline { 2 - 3 } Intercept & 0.0038 & 0.0029 \\
Return - Local Index & $(0.54)$ & $(0.40)$ \\
Return - World Index & 0.5642 & 0.5642 \\
& $(25.72)$ & $(25.71)$ \\
Cross-listing week - Dummy variable & 0.0427 & 0.0431 \\
& $(0.35)$ & $(0.36)$ \\
Post-Cross-listing week - Dummy variable & 0.0018 & 0.0019 \\
Return - Local Index * Post-cross-listing week dummy & $(0.20)$ & $(0.21)$ \\
Return - World Index * Post-cross-listing week dummy & 0.0046 & 0.0047 \\
2nd ADR listing dummy & $(2.43)$ & $(2.47)$ \\
3rd ADR listing dummy & 0.1073 & 0.1077 \\
Inverse Mills Ratio & $(3.70)$ & $(3.71)$ \\
Rountry dummies & -0.3994 & -0.4000 \\
\hline
\end{tabular}

Note. The sample includes information from Argentina, Brazil, Chile and Mexico for the period January 01, 1992 to December 31, 2002. The stocks traded in less than $30 \%$ of the available trading days are not included in the sample. The reported coefficients correspond to the following International Asset Pricing Model (IAPM):

$$
\begin{aligned}
\mathrm{r}_{\mathrm{it}}= & \alpha_{\mathrm{k}}{ }^{\text {pre }}+\beta_{\mathrm{kd}}{ }^{\text {pre }} \mathrm{r}_{\mathrm{kt}}^{\text {local }}+\beta_{\mathrm{kw}}{ }^{\text {pre }} \mathrm{r}_{\mathrm{t}}^{\text {world }}+\alpha_{\mathrm{k}}{ }^{\text {list }} \mathrm{D}_{\mathrm{it}}^{\text {list }}+ \\
& \alpha_{\mathrm{k}}{ }^{\text {post }} \mathrm{D}_{\mathrm{it}}{ }^{\text {post }}+\beta_{\mathrm{kd}}{ }^{\text {post }} \mathrm{r}_{\mathrm{kt}}{ }^{\text {local }} \mathrm{D}_{\mathrm{it}}{ }^{\text {post }}+\beta_{\mathrm{kw}}{ }^{\text {post }} \mathrm{r}_{\mathrm{t}}^{\text {world }} \mathrm{D}_{\mathrm{it}}^{\text {post }}+\beta_{\mathrm{k}} \lambda_{\mathrm{k}}+\varepsilon_{\mathrm{it}}
\end{aligned}
$$

where $r_{i t}$ refers to the weekly excess returns for stock $i$ in period $t$. The variables $r_{k t}$ local and $r_{t}{ }^{\text {world }}$ refer to the excess return in week $t$ on the k-th domestic stock exchange (were stock $\mathrm{i}$ is listed) and the world market portfolio, respectively. $\mathrm{D}_{\mathrm{it}}{ }^{\text {list }}$ and $\mathrm{D}_{\mathrm{it}}{ }^{\text {post }}$ are dummy variables to control for the cross-listing and post-cross-listing weeks. $\lambda_{\mathrm{k}}$ is the average Inverse Mills ratio for each stock, and is included to control sample selection bias. Consistent with the analysis done for the cross-listed stocks, the implementation of this regression includes 24 months of information around the first three ADR listing. Dummy variables are included to control for possible country differences and differences across the first, second and third ADR listing. Robust t-statistics are included in parenthesis. 
Table 7.

Singly Listed Stock Returns: Persistence in the Pre- and Post-Cross Listing Differences

\begin{tabular}{|c|c|c|c|}
\hline & 4 th & 5 th & 6 th \\
\hline \multirow[t]{2}{*}{ Intercept } & 0.0021 & 0.0221 & 0.0023 \\
\hline & $(1.67)$ & $(1.72)$ & $(1.79)$ \\
\hline \multirow[t]{2}{*}{ Return - Local Index } & 0.6573 & 0.6554 & 0.6537 \\
\hline & $(29.01)$ & $(28.76)$ & $(28.75)$ \\
\hline \multirow[t]{2}{*}{ Return - World Index } & -0.0434 & -0.0425 & -0.0405 \\
\hline & $(1.06)$ & $(1.04)$ & $(1.00)$ \\
\hline \multirow[t]{2}{*}{ Return - Local Index * Dummy 1993} & 0.1131 & 0.0315 & 0.0263 \\
\hline & $(1.80)$ & $(0.44)$ & $(0.35)$ \\
\hline \multirow[t]{2}{*}{ Return - Local Index * Dummy 1994} & 0.0010 & 0.0029 & -0.0240 \\
\hline & $(0.04)$ & $(0.11)$ & $(0.87)$ \\
\hline \multirow[t]{2}{*}{ Return - Local Index * Dummy 1995} & -0.1485 & -0.1467 & -0.1452 \\
\hline & $(5.47)$ & $(5.38)$ & $(5.34)$ \\
\hline \multirow[t]{2}{*}{ Return - Local Index * Dummy 1996} & -0.1338 & -0.1320 & -0.1294 \\
\hline & $(3.89)$ & $(3.82)$ & $(3.76)$ \\
\hline \multirow[t]{2}{*}{ Return - Local Index * Dummy 1997} & -0.1305 & -0.1286 & -0.1267 \\
\hline & $(4.44)$ & $(4.35)$ & $(4.31)$ \\
\hline \multirow[t]{2}{*}{ Return - Local Index * Dummy 1998} & -0.1318 & -0.1299 & -0.1286 \\
\hline & $(4.44)$ & $(4.93)$ & $(4.90)$ \\
\hline \multirow[t]{2}{*}{ Return - Local Index * Dummy 1999} & 0.0833 & -0.0851 & 0.0872 \\
\hline & $(3.11)$ & $(3.16)$ & $(3.26)$ \\
\hline \multirow[t]{2}{*}{ Return - Local Index * Dummy 2000} & -0.1835 & -0.1816 & -0.1800 \\
\hline & $(6.25)$ & $(6.16)$ & $(6.12)$ \\
\hline \multirow[t]{2}{*}{ Return - Local Index * Dummy 2001} & -0.1197 & -0.1178 & -0.1163 \\
\hline & $(4.60)$ & $(4.50)$ & $(4.46)$ \\
\hline \multirow[t]{2}{*}{ Return - Local Index * Dummy 2002} & -0.0354 & -0.0335 & -0.0320 \\
\hline & $(1.42)$ & $(1.34)$ & $(1.28)$ \\
\hline
\end{tabular}

Note. The sample includes information from Argentina, Brazil, Chile and Mexico for the period January 01, 1992 to December 31,2002. The stocks traded in less than $30 \%$ of the available trading days are not included in the sample. The reported coefficients correspond to the following regression equation:

$$
\begin{aligned}
& \mathrm{r}_{\mathrm{it}}=\alpha_{\mathrm{k}}+\beta_{\mathrm{kd}} \mathrm{r}_{\mathrm{kt}}^{\text {local }}+\beta_{\mathrm{kw}} \mathrm{r}_{\mathrm{t}}^{\text {world }}+\beta_{\mathrm{k}} \lambda_{\mathrm{k}}+ \\
& \Sigma \beta_{\mathrm{kd}}{ }^{\mathrm{y}} \mathrm{r}_{\mathrm{kt}}{ }^{\text {local }} \mathrm{D}^{\mathrm{y}}+\Sigma \beta_{\mathrm{kw}}{ }^{\mathrm{y}} \mathrm{r}_{\mathrm{t}} \text { world } \mathrm{D}^{\mathrm{y}}+\varepsilon_{\mathrm{it}} \\
& \mathrm{y}=1993 \quad \mathrm{y}=1993
\end{aligned}
$$

where $r_{i t}$ refers to the weekly excess returns for stock $i$ in period $t$. The variables $r_{k t}$ local and $r_{t}$ world refer to the excess return in week $\mathrm{t}$ on the $\mathrm{k}$-th domestic stock exchange (were stock $\mathrm{i}$ is listed) and the world market portfolio, respectively. $\mathrm{D}^{\mathrm{yt}}$ is a dummy variables that takes a value of 1 for year $\mathrm{y} . \lambda_{\mathrm{k}}$ is the average Inverse Mills ratio for each stock, and is included to control sample selection bias. The information corresponds to the stock and exchange information after the 4th, 5th and 6th ADR listing. Robust t-statistics are included in parenthesis. 
Table 7 (Continued)

\begin{tabular}{|c|c|c|c|}
\hline & 4th & 5 th & 6 th \\
\hline \multirow[t]{2}{*}{ Return - World Index * Dummy 1993} & 0.0805 & 0.0123 & -0.0191 \\
\hline & $(0.43)$ & $(0.06)$ & $(0.09)$ \\
\hline \multirow[t]{2}{*}{ Return - World Index * Dummy 1994} & -0.1221 & -0.1229 & -0.0819 \\
\hline & $(1.67)$ & $(1.67)$ & $(1.10)$ \\
\hline \multirow[t]{2}{*}{ Return - World Index * Dummy 1995} & -0.2365 & -0.2384 & -0.2353 \\
\hline & $(2.85)$ & $(2.87)$ & $(2.85)$ \\
\hline \multirow[t]{2}{*}{ Return - World Index * Dummy 1996} & 0.0903 & 0.0891 & -0.0881 \\
\hline & $(1.52)$ & $(1.50)$ & $(1.49)$ \\
\hline \multirow[t]{2}{*}{ Return - World Index * Dummy 1997} & 0.0435 & 0.0424 & 0.0411 \\
\hline & $(0.78)$ & $(0.76)$ & $(0.74)$ \\
\hline \multirow[t]{2}{*}{ Return - World Index * Dummy 1998} & 0.0527 & 0.0515 & 0.0509 \\
\hline & $(1.04)$ & $(1.01)$ & $(1.00)$ \\
\hline \multirow[t]{2}{*}{ Return - World Index * Dummy 1999} & -0.0580 & -0.0590 & -0.0606 \\
\hline & $(1.18)$ & $(1.19)$ & $(1.23)$ \\
\hline \multirow[t]{2}{*}{ Return - World Index * Dummy 2000} & -0.0033 & -0.0041 & -0.0062 \\
\hline & $(0.07)$ & $(0.09)$ & $(0.13)$ \\
\hline \multirow[t]{2}{*}{ Return - World Index * Dummy 2001} & 0.0963 & 0.0955 & 0.0933 \\
\hline & $(2.08)$ & $(2.06)$ & $(2.02)$ \\
\hline \multirow[t]{2}{*}{ Return - World Index * Dummy 2002} & 0.0527 & 0.0520 & 0.0494 \\
\hline & $(1.11)$ & $(1.09)$ & $(1.05)$ \\
\hline Inverse Mills Ratio & Yes & Yes & Yes \\
\hline Country dummies & Yes & Yes & Yes \\
\hline F-Test: All local dummies $=0$ & 28.59 & 27.64 & 26.24 \\
\hline F-Test: All world dummies $=0$ & 4.47 & 4.45 & 4.13 \\
\hline R-Square & 0.1323 & 0.1322 & 0.1314 \\
\hline
\end{tabular}


Table 8 .

Singly-and Cross-Listed Stock Returns: Long-Run Differences

\begin{tabular}{|c|c|c|c|c|c|}
\hline & (I) & (II) & (III) & (IV) & (V) \\
\hline \multirow[t]{2}{*}{ Intercept } & 0.0025 & 0.0021 & 0.0027 & 0.0025 & 0.0026 \\
\hline & $(2.68)$ & $(3.21)$ & $(6.35)$ & $(2.38)$ & $(3.81)$ \\
\hline \multirow[t]{2}{*}{ Return - Local Index } & 0.6116 & 0.6152 & 0.6151 & 0.6113 & 0.6149 \\
\hline & $(147.53)$ & $(148.93)$ & $(148.86)$ & $(147.43)$ & $(148.75)$ \\
\hline \multirow[t]{2}{*}{ Return - World Index } & -0.0313 & -0.0401 & -0.0408 & -0.0312 & -0.0406 \\
\hline & $(3.19)$ & $(4.12)$ & $(4.19)$ & $(3.17)$ & $(4.17)$ \\
\hline \multirow[t]{2}{*}{ Cross-listing week - Dummy variable } & 0.0163 & 0.0164 & 0.0166 & 0.0163 & 0.0166 \\
\hline & $(2.35)$ & $(2.37)$ & $(2.39)$ & $(2.35)$ & $(2.40)$ \\
\hline Post-Cross-listing week - Dummy variable & $\begin{array}{l}-0.0019 \\
(2.93)\end{array}$ & $\begin{array}{c}-0.00247 \\
(3.85)\end{array}$ & $\begin{array}{c}-0.0023 \\
(3.48)\end{array}$ & $\begin{array}{l}-0.0018 \\
(2.63)\end{array}$ & $\begin{array}{c}-0.0021 \\
(3.19)\end{array}$ \\
\hline $\begin{array}{l}\text { Return - Local Index * Post-cross-listing week } \\
\text { dummy }\end{array}$ & $\begin{array}{l}0.1587 \\
(17.89)\end{array}$ & $\begin{array}{l}0.1571 \\
(17.71)\end{array}$ & $\begin{array}{l}0.1571 \\
(17.71)\end{array}$ & $\begin{array}{l}0.1591 \\
(17.93)\end{array}$ & $\begin{array}{l}0.1574 \\
(17.74)\end{array}$ \\
\hline $\begin{array}{l}\text { Return - World Index * Post-cross-listing week } \\
\text { dummy }\end{array}$ & $\begin{array}{l}0.1044 \\
(5.38)\end{array}$ & $\begin{array}{c}0.1091 \\
(5.62)\end{array}$ & $\begin{array}{c}0.1089 \\
(5.61)\end{array}$ & $\begin{array}{l}0.1043 \\
(5.37)\end{array}$ & $0.1088(5.60)$ \\
\hline Inverse Mills Ratio & Yes & Yes & Yes & Yes & Yes \\
\hline Year dummies & Yes & & & Yes & \\
\hline Country dummies & & Yes & & Yes & Yes \\
\hline Post-1997 dummy & & & Yes & & Yes \\
\hline R-Square & 0.1631 & 0.1624 & 0.1623 & 0.1631 & 0.1624 \\
\hline
\end{tabular}

Note: The sample includes information from Argentina, Brazil, Chile and Mexico for the period January 01, 1992 to December 31, 2002. The stocks traded in less than $30 \%$ of the available trading days are not included in the sample. The reported coefficients correspond to the following International Asset Pricing Model (IAPM):

$\mathrm{r}_{\mathrm{it}}=\alpha_{\mathrm{k}}^{\text {pre }}+\beta_{\mathrm{kd}}{ }^{\text {pre }} \mathrm{r}_{\mathrm{kt}}^{\text {local }}+\beta_{\mathrm{kw}}^{\text {pre }} \mathrm{r}_{\mathrm{t}}^{\text {world }}+\alpha_{\mathrm{k}}^{\text {list }} \mathrm{D}_{\mathrm{it}}^{\text {list }}+$

$$
\alpha_{\mathrm{k}}{ }^{\text {post }} \mathrm{D}_{\mathrm{it}}^{\text {post }}+\beta_{\mathrm{kd}}{ }^{\text {post }} \mathrm{r}_{\mathrm{kt}}{ }^{\text {local }} \mathrm{D}_{\mathrm{it}}{ }^{\text {post }}+\beta_{\mathrm{kw}}{ }^{\text {post }} \mathrm{r}_{\mathrm{t}}{ }^{\text {world }} \mathrm{D}_{\mathrm{it}}{ }^{\text {post }}+\beta_{\mathrm{k}} \lambda_{\mathrm{k}}+\varepsilon_{\mathrm{it}}
$$

where $r_{i t}$ refers to the weekly excess returns for stock $i$ in period $t$. The variables $r_{k t}^{\text {local }}$ and $r_{t}$ world refer to the excess return in week $t$ on the k-th domestic stock exchange (were stock $\mathrm{i}$ is listed) and the world market portfolio, respectively. $\mathrm{D}_{\mathrm{it}}{ }^{\text {list }}$ and $\mathrm{D}_{\mathrm{it}}{ }^{\text {post }}$ are dummy variables to control for the cross-listing and post-cross-listing weeks for the cross-listed stocks; for the singly-listed stocks this dummy variables will always be equal to zero. $\lambda_{\mathrm{k}}$ is the average Inverse Mills ratio for each stock, and is included to control for any difference across singly- and cross-listed stocks. All the information of singly- and cross-listed stocks is pooled to estimate the regression coefficients. Additional dummy variables are included to control for possible country differences, time trends and post-1997 events. Robust t-statistics are included in parenthesis. 